\title{
Editorial
}

\section{Management of Medical Waste - a Growing Concern}

\author{
SK Saha ${ }^{1}$, RU Ahmad ${ }^{2}$
}

Health care facilities, both government and nongovernment, are increasing day by day in our country. Proportionately more and more medical wastes are being generated. But waste management issue has not got enough attention by the concerned authority. The medical waste can be defined as all waste materials generated at health care facilities such as hospitals, clinics, physician's offices, dental practices, blood banks, and veterinary hospitals/clinics as well as medical research facilities and laboratories ${ }^{1}$. Waste produced in the course of health care activities carries a higher potential for infection and injuries than any other type of waste ${ }^{2}$. Approximately $85 \%$ of hospital waste are actually non-hazardous, $10 \%$ are infectious and around $5 \%$ are non-infectious but hazardous ${ }^{3}$. Non infectious hazardous waste includes sharp items, radioactive substances, pharmaceuticals, chemicals, laboratory reagent, etc. Usually these wastes are disposed of in an open dust bin. Scavengers pick up some items for selling and pose a negative impact on health and environment. Proper management and safe disposal of medical waste is vital in the reduction of infection or illness through contact with discarded material and in the prevention of environmental contamination in hospital facilities ${ }^{4}$. In most cases the main reason of mismanagement of clinical wastes are the lack of legislation, lack of specialized clinical staffs, lack of awareness and effective control ${ }^{5}$. Segregation of potentially infectious/hazardous materials from non-hazardous waste at the point of generation may reduce both volume and $\cos \mathrm{t}^{6}$. Illegal segregation and recycling of medical waste is carried out at the final disposal site, therefore there are concern about environmental pollution and transmission of infectious diseases ${ }^{7}$.

Segregation of hazardous from non- hazardous items at the point of generation of waste is very important. Hazardous item may be treated/disposed of in the following ways according to the nature of waste: incineration, autoclaving, chemical treatment, inertization and sanitary landfilling ${ }^{2}$. Non-hazardous

\footnotetext{
1. Dr. Sanjay Kumar Saha, MBBS, DCP, M Phil (Micro), Assistant Professor, Department of Microbiology, Faridpur Medical College, Faridpur.

2. Dr. Rafi Uddin Ahmad, MBBS, D Bact, MSc (Micro), M Phil (Viro), Assistant Professor, Department of Micobiology, Faridpur Medical College, Faridpur.
}

Address of correspondence :

Dr. Sanjay Kumar Saha, MBBS, DCP, M Phil (Micro), Assistant professor, Department of Microbiology, Faridpur Medical College, Faridpur. Mobile Phone: +8801711783079 Email: drsanjay1961@gmail.com item may be dumped on open land followed by final removal by an authorized agency. Training and capacity building program for all employees involved in the management of medical waste is urgently needed. To do no harm is an ethical issue. To develop a safe and sustainable waste management system all over the country, implementation of national medical waste management and processing rules, 2008 as well as the WHO core principles for health care waste management is imperative . $^{8}$.

\section{References :}

1. Akter N. Medical Waste Management: A Review. [Dissertation]. Department of Environmental Engineering Program, School of Enviroment, Resources and Development in Asian Institute of Technology. January 2000.

2. Park K. Text book of preventive and social medicine. 21th ed. M/S Banarsidas Bhanot publishers: Jabalpur, India; 2011.p.730-5.

3. McRae G, Agarwal R. Clinical Waste in Developing Countries. Basel Action Network(BAN) and Health Care Waste Without Harm (HCWH) (1999). Basel Action Network(BAN) Secretariate, Asia-Pacific Environmental exchange:USA; 1999.p.3.

4. Idowu IA, Alo B, Atherton W, Khaddar RM. Profile of medical waste management in two health care facilities in Lagos, Nigeriaa case study. Waste Manage Res. 2013 mar.4 [Epub ahed of print].

5. Hossain MS, Santhanam A, Nik Norulaini NA, Omar AK(2011).Clinical solid waste management, practice and its impact on human health and environment- A review. Waste mang. 2011;Apr 31(4):754-66.doi:10.1016/j.wasman.2010.11.008. Epub2010Dec24.

6. Fay MF, Beck WC, Fay JM, Kessinger MK. Medical waste-The growing issues of management and disposal. AORNJ. 1990; 51(6): 1493-1508.

7. Taquipour H, Mosaferi M. The challenge of medical waste management: a case study in northwest Iran-Tabriz. Waste management Res. 2009; 27(4): 328-35. doi:10.1177/0734242X091 04132 .

8. WHO core principles for achieving safe and sustainable management of health care waste; developed during the International Health Care Waste meeting hosted by WHO in Geneva on June 20-22, 2007. 